\title{
Glucose-responsive beta cells in islets isolated from a patient with long-standing type 1 diabetes mellitus
}

\author{
J. N. Walker • P. R. V. Johnson • M. Shigeto • \\ S. J. Hughes • A. Clark • P. Rorsman
}

Received: 2 June 2010 /Accepted: 1 September 2010 /Published online: 21 October 2010

(C) Springer-Verlag 2010

Keywords Alpha · Beta - Diabetes · Glucagon - Insulin . Islet $\cdot$ Isolation $\cdot$ Long-standing $\cdot$ Survival $\cdot$ Type 1 diabetes

To the Editor: The heterogeneous nature of the autoimmune process in type 1 diabetes mellitus can, on occasion, result in the preservation of beta cells in patients with longstanding disease [1]. The detection of low levels of basal C-peptide secretion in these patients suggests some beta cell secretory capacity [2]. Whether these residual beta cells are functionally intact, however, remains unanswered. Here we report in vitro observations on islets isolated from a cadaveric donor who had had type 1 diabetes mellitus for 13 years. The objectives were to isolate islets from the pancreas to determine islet hormone secretion profiles and cellular electrophysiological responses, and to compare these variables with data from islets from non-diabetic donors. In addition, we compared the pancreatic histology of this donor pancreas with that of other type 1 diabetic mellitus donors with established or newly diagnosed disease.

The donor, a white female, was 19 years old at diagnosis, weighed $73.8 \mathrm{~kg}\left(\right.$ BMI $28 \mathrm{~kg} / \mathrm{m}^{2}$ ) and had no family history of diabetes. She was treated with gliclazide

J. N. Walker · P. R. V. Johnson · S. J. Hughes

Nuffield Department of Surgery,

University of Oxford, John Radcliffe Hospital,

Oxford, UK

J. N. Walker $(\bowtie) \cdot$ P. R. V. Johnson $\cdot$ M. Shigeto $\cdot$ S. J. Hughes $\cdot$

A. Clark $\cdot$ P. Rorsman

Oxford Centre for Diabetes, Endocrinology and Metabolism,

University of Oxford, Churchill Hospital,

Oxford OX3 7LJ, UK

e-mail: neil.walker@nds.ox.ac.uk and metformin. Seven weeks after diagnosis, despite maximal doses of oral therapy, she developed ketonuria and had a fasting blood glucose of $24 \mathrm{mmol} / \mathrm{l}$. She therefore started insulin treatment $(0.27 \mathrm{U} / \mathrm{kg}$ insulin twice daily). This was increased to $0.6 \mathrm{U} / \mathrm{kg}$ using a basal bolus regimen over a 6 month period. She underwent four admissions for severe diabetic ketoacidosis. Unfortunately no serum samples were taken for determination of C-peptide or antibody status at any time. Samples taken at the time of death showed HLA-DR3 and -4 positivity.

The donor's pancreas was retrieved for research with the informed consent of the family and with the approval of the local ethics committee. Islets were isolated using established protocols [3]. An islet count was omitted as poor dithizone uptake was predicted. Islets that were visibly structurally intact were hand-picked from the purified digest for the secretion experiments and the residual islets were retained for morphological analysis. The islets used for the functional experiments were therefore not a true representation of the whole isolated population. Insulin and glucagon secretion was measured from batches of 15 islets (in quadruplicates) pre-incubated in $1 \mathrm{mmol} / \mathrm{l}$ glucose for $1 \mathrm{~h}$ followed by incubation for $1 \mathrm{~h}$ at 1,6 or $20 \mathrm{mmol} / 1$ glucose. The hormone contents of islets and supernatant fractions were determined by radioimmunoassay [4]. Membrane capacitance, as a measure of insulin granule exocytosis, was recorded from isolated alpha and beta cells using the patch-clamp technique [5]. Pancreatic tissue samples taken from the body and tail regions of this donor pancreas and from the donor pancreases of three additional type 1 diabetic patients (diabetes duration $>10$ years, $n=2$; diabetes duration $<48 \mathrm{~h}, n=1$; tissue retrieval at post mortem was approved by the local ethics committee) were prepared for light and electron microscopy [6]; they were 
then immunolabelled with anti-insulin (in-house antibody), anti-glucagon (Sigma, Poole, UK), anti-somatostatin (DAKO, Glostrup, Denmark) and markers for macrophages (anti-human CD68; DAKO) and lymphocytes (anti-human CD45; DAKO).

Islet insulin content from the type 1 diabetic donor was lower than the median of size-matched control islets (isolated from a cohort of non-diabetic donors of similar age) but still within the same range (21.1 vs median $37.7 \mathrm{ng} /$ islet [range 16.1-47.2], $n=5$ ). Glucose-stimulated insulin secretion was comparable to that of controls (2.9-fold vs median 3.7-fold increase between 1 and $20 \mathrm{mmol} / 1$ glucose [range 2-6.1]). (Stimulated insulin secretion at $20 \mathrm{mmol} / \mathrm{l}$ was 0.24 vs median $0.31 \mathrm{ng}$ islet $^{-1} \mathrm{~h}^{-1}$ [range 0.18-0.49].) Beta cell exocytosis in response to voltage-clamp depolarisation steps was also comparable to controls. Glucagon content per islet was higher than that found in controls $(2,106.6 \mathrm{vs}$ median 827.3 pg/islet [range 761.1-1,053.9], $n=5$ ). Although alpha cell exocytosis in response to voltage-clamp depolarisations was similar to that of controls, glucagon secretion was not suppressed by elevation of glucose concentration (controls: median 32\% suppression [range 20-55\%])

Histological section analysis of 182 islets in specimens from the body and tail regions revealed that $85 \%$ of the islets from the type 1 diabetic donor contained no insulinpositive cells; all of the insulin-positive cells (15\%) (Fig. 1a, b) were found in the specimen from the tail region. A subgroup of these insulin-positive islets $(40 \%)$ contained a normal proportion of beta cells $(>50 \%$ of insulin-positive area per islet area [7]). There were varying degrees of inflammatory infiltrate in the insulin-positive islets; extensive infiltration (Fig. 1c) was associated with islets with reduced insulin positivity. Infiltrates contained CD45 and CD68 inflammatory cells (Fig. 1d) and were similar to those seen surrounding islets in the new-onset type 1 diabetic patient and in other reported literature [8]. The insulin-negative islets contained no infiltrate. Islets
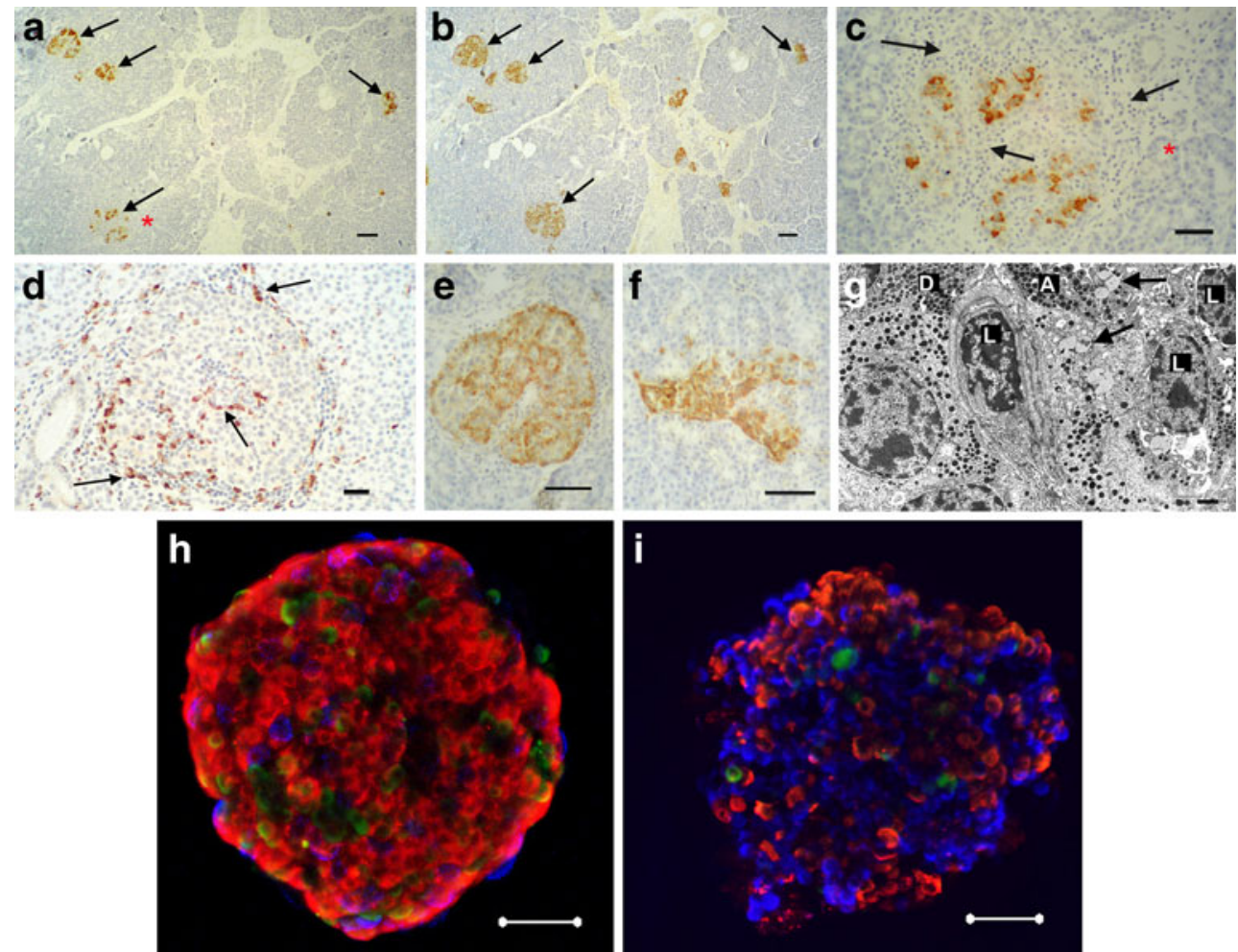

Fig. 1 Pancreatic islets from the type 1 diabetic donor. a Insulinpositive islets (arrows) were restricted to small numbers of exocrine lobules of the pancreatic tail region; $\mathbf{b}$ adjacent section labelled for glucagon identified more islets in other lobules. c Higher magnification of the islet indicated with a red asterisk in a shows an insulinpositive islet surrounded by extensive mononuclear infiltrates (arrows). d The inflammatory infiltrate surrounding insulin-positive islets contained cells that were positive for the macrophage marker CD68 (arrows). e Higher magnification of an islet in $\mathbf{b}$ (known to contain insulin-positive cells) stained for glucagon showed normal ovoid morphology with glucagon-containing alpha cells on the periphery and adjacent to islet capillaries; $\mathbf{f}$ an islet (containing no insulin-positive cells) that consisted almost entirely of alpha cells and was dysmorphic in structure. g Electron microscopy demonstrated lymphocytes (L) within an islet. A, alpha cell; D, delta cell. Lipofuscin bodies are noted in the alpha cell (arrows) indicating that this was not a neogenic cell. Confocal reconstructions of an isolated islet from a non-diabetic donor $\mathbf{h}$ and the type 1 diabetic donor $\mathbf{i}$ immunolabelled for insulin (red), glucagon (blue) and somatostatin (green); this illustrates an islet with low levels of insulin positivity. Scale bars: a, b $150 \mu \mathrm{m}$; c $50 \mu \mathrm{m}$; d $25 \mu \mathrm{m}$; e, f $50 \mu \mathrm{m}$; g $1.0 \mu \mathrm{m}$; h, i $50 \mu \mathrm{m}$ 
containing insulin were not dysmorphic in structure (Fig. 1e), but the majority of islets with no insulinpositive cells were no longer ovoid with well-defined margins (Fig. 1f). It is unlikely that these dysmorphic islets would have survived the isolation process.

Electron microscopy demonstrated lymphocytic infiltrates in islets (Fig. 1g). Lipofuscin bodies were noted within the alpha cells, suggesting that the islet cells were not neogenic [6]. Confocal Z-stack reconstruction of an islet isolated from a non-diabetic donor and from the type 1 diabetic donor illustrates an islet with low levels of insulin-positive beta cells relative to glucagon-positive alpha cells in the latter (Fig. 1h, i). Islets from the other patients with long-standing disease $(n=2)$ examined by histology contained no insulinpositive cells or inflammatory infiltration, were glucagonpositive and had a dysmorphic structure.

Although the function of islets isolated from a pancreas donor with type 1 diabetes, who died a few months after diagnosis, has been described [9], this is the first reported case to demonstrate glucose-induced insulin secretion from islets isolated from a donor with long-standing disease. It confirms that, even after 13 years of type 1 diabetes, some islets retain a high population of beta cells. In addition, it demonstrates that the residual beta cells remain responsive to glucose, although the abundant alpha cells were not responsive to changes in glucose concentration. The observed impaired response of the alpha cells may contribute to the counterregulatory dysfunction known to occur in these patients [10].

Acknowledgements This work was supported by the National Institute of Health Research (NIHR) Biomedical Research Centre, Oxford. We thank the family for consenting to allow the pancreas to be used for research. We also thank E. Maillard and J. Gray for their help with the isolation of human islets, Q. Zhang for his help with the confocal imaging, A. Tajer for her help with the patient clinical information, and D. Wiggins and R. Ramracheya for assistance with hormone release measurements.
Duality of interest statement The authors declare that there is no duality of interest associated with this manuscript.

\section{References}

1. Gianani R, Campbell-Thompson M, Sarkar SA et al (2010) Dimorphic histopathology of long-standing childhood-onset diabetes. Diabetologia 53:690-698

2. Liu EH, Digon BJ 3rd, Hirshberg B et al (2009) Pancreatic beta cell function persists in many patients with chronic type 1 diabetes, but is not dramatically improved by prolonged immunosuppression and euglycaemia from a beta cell allograft. Diabetologia 52:1369-1380

3. Shapiro AM, Lakey JR, Ryan EA et al (2000) Islet transplantation in seven patients with type 1 diabetes mellitus using a glucocorticoid-free immunosuppressive regimen. N Engl J Med 343:230-238

4. Braun M, Ramracheya R, Bengtsson M et al (2010) GABA is an autocrine excitatory transmitter in human pancreatic $\beta$-cells. Diabetes 59:1694-1701

5. Braun M, Ramracheya R, Bengtsson M et al (2008) Voltage-gated ion channels in human pancreatic beta-cells: electrophysiological characterization and role in insulin secretion. Diabetes 57:16181628

6. Cnop M, Hughes SJ, Igoillo-Esteve M et al (2010) The long lifespan and low turnover of human islet beta cells estimated by mathematical modelling of lipofuscin accumulation. Diabetologia 53:321-330

7. Clark A, Wells CA, Buley ID et al (1988) Islet amyloid, increased A-cells, reduced B cells and exocrine fibrosis: quantitative changes in the pancreas in type 2 diabetes. Diabetes Res 9:151159

8. Willcox A, Richardson SJ, Bone AJ, Foulis AK, Morgan NG (2009) Analysis of islet inflammation in human type 1 diabetes. Clin Exp Immunol 155:173-181

9. Marchetti P, Dotta F, Ling Z et al (2000) Function of pancreatic islets isolated from a type 1 diabetic patient. Diabetes Care 23:701-703

10. Rickels MR, Schutta MH, Mueller R et al (2005) Islet cell hormonal responses to hypoglycemia after human islet transplantation for type 1 diabetes. Diabetes 54:3205-3211 